\title{
A Brief Survey on Fuzzy Logic Systems for Performance Appraisal
}

\author{
Ramit Manuja \\ M.Tech Student \\ Department of CSE \\ PIET, Samalkha
}

\author{
Sandeep Singh Bindra \\ Assistant Professor \\ Department of CSE \\ PIET, Samalkha
}

\author{
S. C. Gupta, PhD \\ Professor and Head \\ Department of CSE \\ PIET, Samalkha
}

\begin{abstract}
Effective monitoring of student's performance is an important task for successful higher learning. Performance appraisal enables institutions to foresee student progression as well as inform the students well in time, the areas they need to improve. Traditional evaluation methods do not fully justify these objectives whereas Fuzzy logic based appraisal approaches are like human inference and give better evaluation results. In this paper we describe the advantages of the fuzzy logic approach for performance evaluation over the traditional method as fuzzy expert system can be built not only with the given information in the dataset but can also include the vital knowledge of experts at various levels as and when required. Furthermore, various existing approaches using fuzzy logic approach in this field have been investigated and compared for their merits and demerits.
\end{abstract}

\section{Keywords}

Effective monitoring, Performance appraisal, Fuzzy logic, Human inference, Fuzzy expert system

\section{INTRODUCTION}

In today's Educational institutions, the students are given merit primarily based on their academic performance that is how well a student adheres to the institution rules and governmental educational standards [1]. Ideally an assessment should describe skills, beliefs, caliber and attitude of the student but these days, the annual assessments are merely done by documenting in measurable terms, knowledge depending on the chosen criteria. These hard core methodologies lack flexibility and thus yield different outcomes of assessment for the same person under slight varying parameters. Moreover classical methods of evaluation just give numbers with less significant information about the students.

So in order to have more realistic evaluation and monitoring of student performance, Fuzzy logic approach can be of great help [2]. The use of Fuzzy logic reasoning in this field is quite new. Fascinating researches have been reported in this direction using fuzzy logic.

The following table summarizes the advantages of Fuzzy logic approach over traditional evaluation technique.
Table 1: Difference between Traditional and Fuzzy Logic Systems for Performance Evaluation

\begin{tabular}{|c|c|c|}
\hline $\begin{array}{l}\text { Difference } \\
\text { Criteria }\end{array}$ & $\begin{array}{c}\text { Traditional } \\
\text { Evaluation } \\
\text { Methods }\end{array}$ & $\begin{array}{l}\text { Fuzzy logic } \\
\text { Systems }\end{array}$ \\
\hline Type of Control & $\begin{array}{l}\text { Point to point } \\
\text { control }\end{array}$ & $\begin{array}{l}\text { Point to range or } \\
\text { range to range } \\
\text { control }\end{array}$ \\
\hline Ease of Use & $\begin{array}{l}\text { Less friendly for } \\
\text { human } \\
\text { conception. }\end{array}$ & $\begin{array}{l}\text { More closer to } \\
\text { human inference }\end{array}$ \\
\hline $\begin{array}{c}\text { Ease of } \\
\text { Implementation }\end{array}$ & $\begin{array}{l}\text { Works well with } \\
\text { existing computer } \\
\text { systems }\end{array}$ & $\begin{array}{l}\text { Requires fuzzy } \\
\text { logic to be } \\
\text { incorporated in } \\
\text { present systems }\end{array}$ \\
\hline Extensibility & $\begin{array}{l}\text { Fixed rules } \\
\text { approach }\end{array}$ & $\begin{array}{c}\text { Flexible and can } \\
\text { incorporate } \\
\text { variations } \\
\end{array}$ \\
\hline $\begin{array}{c}\text { External } \\
\text { knowledge }\end{array}$ & $\begin{array}{l}\text { Doesn't include } \\
\text { any expert } \\
\text { knowledge }\end{array}$ & $\begin{array}{c}\text { Can add } \\
\text { knowledge from } \\
\text { experts in the field } \\
\text { to have better } \\
\text { decision making }\end{array}$ \\
\hline
\end{tabular}

Thus from above comparison it is clear that Fuzzy logic approaches prove to be lot better and accurate as compared to traditional evaluation techniques on various grounds. Furthermore Fuzzy logic can also aid to improve learning experiences for students and faculty [3].

\section{FUZZY LOGIC AND FUZZY INFERENCE TECHNIQUE}

Fuzzy Logic is an idea similar to the feeling and decision making of human beings [4]. The idea of fuzzy logic was pioneered by Professor L. A. Zadeh [6] in 1965 at University of California (Berkley). The first practical application of the Fuzzy logic came as a control of an automatic steam engine by Dr. E. H. Mamdani [8] in 1974 at London University. Fuzzy logic ideas are quite common in our daily routine like the answers to many questions in a survey are 'not very satisfied' or 'quite satisfied' which are fuzzy or ambiguous answers. Such type of answers can only be created and implemented by human beings. But in order to make computer systems handle those ambiguous data, we need some fuzzy logic techniques. Hence fuzzy logic is primarily range to point or range to range control strategy unlike the traditional strategy which is point to point control. Also a fuzzy process is a process of crisp to fuzzy to crisp for a real system [5]. That is the initial fixed values input to the fuzzy systems are first converted to fuzzy input value which is 
processed to get the fuzzy output from the system. This fuzzy output is finally converted back to fixed crisp value.

The architecture of the Fuzzy logic system can be described as follows in Figure1.

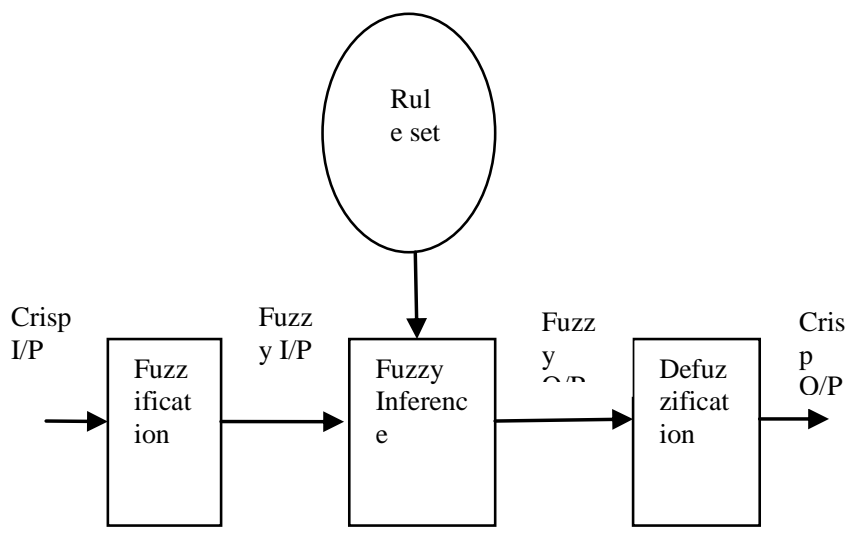

Figure 1: Architecture of Fuzzy logic system

Thus to incorporate the fuzzy logic technique into a real application following steps need to be followed:

\subsection{Fuzzification}

Fuzzification is the initial step to apply to a fuzzy inference system. Most of the variables in the real world applications tend to be crisp or classical variables. In order to implement fuzzy logic these crisp variables need to be converted to fuzzy variables and then apply fuzzy inference to that data to obtain the final output. Fuzzification involves following two sub processes:

i. Deriving the membership functions for input and output variables.

ii. Representation with Linguistic variables [6].

Thus Fuzzification process can be said equivalent to converting classical set to fuzzy set to variable degrees.

\subsection{Fuzzy Inference Technique}

This step processes the membership functions with the control rules to obtain the fuzzy output [7].

i. Fuzzy control rules: fuzzy control rules are the added knowledge of experts in any field of consideration. These are generally the sequences of IF-THEN which describe what output is to be produced in terms of current information input in form of linguistic variables.

\subsection{Defuzzification}

The result derived from the combination of input and output membership functions and fuzzy rules is still an ambiguous fuzzy element. Hence, in this step, different methods are used to convert the fuzzy output obtained in the above step to produce the final crisp output. The commonly implemented Defuzzification approaches include Centre of Gravity (COG) method, Mean of Maximum (MOM) method and the Height method.

Along with Student progress evaluation, Fuzzy logic approach has wide range of applications in the Educational domain like curriculum evaluation or educators training evaluation. Thus such issues make the prediction task a challenging one.

\section{LITERATURE REVIEW}

N.A. Kumari et al. [1] have developed a Fuzzy Logic
Inference System (FLIS) for the performance analysis of emerging engineers. Based on Mamdani type FIS, their proposed system fuzzifies the input and output attributes in three linguistic variable (poor, average, good).The results obtained from FLIS are indexed for the purpose of continuous and comprehensive evaluation of students. According to D. Deliktas et al. [2] is multi criteria decision problem including both tangible and intangible factors. They have followed an integrated approach with multi choice goal programming and fuzzy MULTIMOORA. This approach chooses the optimum assignments as per student's ability to enhance the ranking value. The rank of the students and the placement preferences are set as parameters to first and second objective function respectively. S. Deb et al. [4] have put forth a framework of fuzzy logic based Adaptive Behavioral Learning System for better outcomes in learning. In their learning system they have put the students of a class into specific clusters based on the learning ability of individual students. This would enable the educators to customize the teaching methodologies for different clusters which would ensure better understanding of concepts and results of the students.

A. Kharola et al. [5] have given a new fuzzy logic based reasoning approach for performance evaluation of students in school or college. Their stage wise evaluation approach considers the academic as well as the personality traits of students. They have obtained better results in evaluation with their fuzzy approach when compared to traditional methods. A.A. Surya et al. [9] have proposed a flexible fuzzy evaluation system for student performance in school or college. In their system the membership function deployed can be changed as per the need of time and system. M. Guruprasad et al. [10] have used an algorithm in visual basics (VB) to develop a fuzzy logic model for evaluating the performances of faculty members in an institution. They have grouped the weighed values for similarities and comparison of the faculty members based the fuzzy values being calculated by the system.

G. Jyothi et al. [11] have designed an expert system based on fuzzy logic techniques to evaluate overall performance of faculty members. Their system is like a model of optimization evolution which relies on the activity series of qualitative reports for teaching. A. Shout et al. [12] have explored various aspects of fuzzy logic reasoning using a stage wise approach for building inference systems for fuzzy controllers. Their study brought out the fact a stage wise approach is able to eliminate the problem of rule explosion by combining attributes at various stages.

M. H. Wang et al. [13] have developed a mechanism based on adaptive item selection strategy to obtain the current ability of the student. They have demonstrated how both faculty and students can improve their teaching and learning experiences by utilizing the vital information obtained from the system. R. S. Yadav et al. [14] have proposed a new fuzzy expert system using different approaches to evaluate performances of students more practically. Z. Yildiz et al. [15] have presented a model using the fuzzy multi criteria method for student's evaluation in laboratory activities. Their fuzzy decision support systems have given better results when compared to classical systems. N. Arora et al. [16] have developed a evaluation model based on feed forward probabilistic neural networks. Such networks consumes lesser time in training the network. Their evaluation criteria are mostly based on the qualitative observations. S. S. Jamsandekar et al. [17] have used the fuzzy inference technique for the evaluation of performance of students in an institution. They have proposed 
a combination of two membership functions in their model.

\section{COMPARISON OF FUZZY LOGIC APPROACHES FOR ERFORMANCE EVALUATION \\ Table 2: Comparison of fuzzy logic approaches}

\begin{tabular}{|c|c|c|}
\hline $\begin{array}{l}\text { Evaluation } \\
\text { Approach }\end{array}$ & Advantages & Disadvantages \\
\hline $\begin{array}{l}\text { FLIS (Fuzzy } \\
\text { Logic Inference } \\
\text { System) byN. } \\
\text { A. Kumari [1] }\end{array}$ & $\begin{array}{l}\text { Convenient to } \\
\text { apply }\end{array}$ & $\begin{array}{l}\text { Basic Mamdani } \\
\text { approach is } \\
\text { followed without } \\
\text { much latest } \\
\text { inclusions. }\end{array}$ \\
\hline $\begin{array}{c}\text { Fuzzy } \\
\text { MULTIMOOR } \\
\text { A by D. } \\
\text { Deliktas et al. } \\
\text { [2] }\end{array}$ & $\begin{array}{l}\text { Multi criteria } \\
\text { approach }\end{array}$ & $\begin{array}{l}\text { Aims to Rank the } \\
\text { Students and } \\
\text { doesn't aid to } \\
\text { improve Learning } \\
\text { experience. }\end{array}$ \\
\hline $\begin{array}{l}\text { ABLS(Adaptive } \\
\text { Behavioral } \\
\text { Learning } \\
\text { System ) by S. } \\
\text { Deb et al. [4] }\end{array}$ & $\begin{array}{l}\text { Clustering } \\
\text { approach to } \\
\text { frame different } \\
\text { policies for } \\
\text { different } \\
\text { clusters. }\end{array}$ & $\begin{array}{c}\text { Difficult to } \\
\text { implement from } \\
\text { the perspective of } \\
\text { faculty. }\end{array}$ \\
\hline $\begin{array}{l}\text { New Fuzzy } \\
\text { logic Approach } \\
\text { by A. Kharola } \\
\text { et al. [5] }\end{array}$ & $\begin{array}{l}\text { Stage wise } \\
\text { approach helps } \\
\text { in better } \\
\text { evaluation. }\end{array}$ & $\begin{array}{l}\text { Doesn't include } \\
\text { any behavioral or } \\
\text { ability evaluation } \\
\text { in the proposed } \\
\text { system. }\end{array}$ \\
\hline $\begin{array}{l}\text { Flexible fuzzy } \\
\text { evaluation } \\
\text { system by A.A. } \\
\text { Surya et al. [9] }\end{array}$ & $\begin{array}{l}\text { Allows the } \\
\text { change in } \\
\text { membership } \\
\text { function as per } \\
\text { need of the } \\
\text { system. }\end{array}$ & $\begin{array}{l}\text { Only two } \\
\text { membership } \\
\text { functions } \\
\text { deployed. }\end{array}$ \\
\hline $\begin{array}{l}\text { Expert Fuzzy } \\
\text { System by G. } \\
\text { Jyothi et al. [11] }\end{array}$ & $\begin{array}{c}\text { Optimization } \\
\text { evolution model }\end{array}$ & $\begin{array}{c}\text { Relies on activity } \\
\text { series of } \\
\text { Qualitative } \\
\text { reports. }\end{array}$ \\
\hline $\begin{array}{c}\text { Adaptive Item } \\
\text { selection } \\
\text { Strategy by M. } \\
\text { H. Wang et al. } \\
\text { [13] }\end{array}$ & $\begin{array}{l}\text { Improve both } \\
\text { teaching and } \\
\text { learning } \\
\text { experience }\end{array}$ & $\begin{array}{c}\text { Only current } \\
\text { ability of the } \\
\text { student drives the } \\
\text { system. }\end{array}$ \\
\hline $\begin{array}{l}\text { NFES (New } \\
\text { Fuzzy Expert }\end{array}$ & $\begin{array}{l}\text { Deploys } \\
\text { Multiple }\end{array}$ & $\begin{array}{l}\text { Doesn't include } \\
\text { the core Fuzzy } \\
\text { decision making }\end{array}$ \\
\hline
\end{tabular}

\begin{tabular}{|c|c|c|}
\hline $\begin{array}{c}\text { System) by R. } \\
\text { S. Yadav et al. } \\
{[14]}\end{array}$ & $\begin{array}{c}\text { approaches for } \\
\text { Performance } \\
\text { Appraisal }\end{array}$ & systems. \\
\hline $\begin{array}{l}\text { Feed Forward } \\
\text { Probablistic } \\
\text { Fuzzy Neural } \\
\text { network by N. } \\
\text { Arora et al. [16] }\end{array}$ & $\begin{array}{l}\text { Networks } \\
\text { deployed in the } \\
\text { system take } \\
\text { lesser time to } \\
\text { train and } \\
\text { produce better } \\
\text { results. }\end{array}$ & $\begin{array}{l}\text { Complex in } \\
\text { implementation } \\
\text { and extension. }\end{array}$ \\
\hline
\end{tabular}

The above table shows that though all of the existing approaches predict the missing values in a dataset but still they have some significant drawbacks and scope of improvement. They can be further improvised to predict values with higher accuracy so that the data mining tasks applied on them can yield better and accurate conclusions.

\section{CONCLUSION AND FUTURE WORK}

The classical methods for performance appraisal of students in academic institutions mostly adhere to some predefined constant mathematical rule. In contrast to this the fuzzy logic systems have greater reliability and flexibility. If an examination is tough then the membership functions can be altered accordingly. In this paper we have listed the advantages of the Fuzzy approach in student evaluation over traditional methods. Further we reviewed some of the current works done in this direction and compared them all for their merits and demerits. In future, we would work to devise a novel performance appraisal system using fuzzy logic approach to cater the limitations of the existing approaches and get learning experience.

\section{ACKNOWLEDGMENTS}

Special thanks to the experts who have contributed towards development of the paper.

Sandep Singh Bindra, Assistant Professor, Panipat Institute of Engineering and Technology

Dr. S.C Gupta, Professor amd Head of Department , Panipat Institute of Engineering and Technology

\section{REFERENCES}

[1] N. A. Kumari, D. N. Rao, "Indexing Student Performance with Fuzzy Logics Evaluation in Engineering Education”, Issue 9, Volume 4, ISSN 23943386, 2017.

[2] D. Deliktas, O. Ustun, "Student Selection and Assignment Methodology based on Multimoora and multi choice goal programming", International transactions in Operational research, Issue 5, Volume 24, pp. 1173-1195, 2017.

[3] K. Chrysafiadi, M. Virvou, "Evaluating the intergration of Fuzzy logic into the student model of a web learning environment", Elsevier Journal of Expert Systems and Applications, Volume 39, pp. 13127-13134, 2012

[4] S. Deb, P. Bhattacharya, "A Framework to enhance the Learning Outcome with Fuzzy Logic ABLS", Advances in Intelligent Systems and Computing, Volume 564, pp. 3-11, 2017 
[5] A. Kharola, S. Kunwar, "Student Performance Evaluation: A Fuzzy Logic Reasoning Approach", PM world Journal, Issue 4, Volume 9, pp. 1-11, 2015.

[6] L. A. Zadeh, "The Concept of Linguistic Variable and its application to Approximate Reasoning", Information Sciences, Volume 8, pp. 199-249, 1975.

[7] S. G. Tzafestas, S. Terjakis, "Fuzzy Sets and Fuzzy Reasoning: An Introduction", Fuzzy Reasoning in Information and Decision Control Systems, pp. 3-29, 1994.

[8] A. Kaur, A.Kaur, "Comparison of Mamdani type and Surgeno type Fuzzy Inference System for AC system", International Journal of Soft Computing and Engineering (IJSCE), Issue 2, Volume 2, pp. 325-329, 2012.

[9] A. A. Surya, M. K. Kurian, "Overall Performance Evaluation Engineering Students using Fuzzy Logic", International Journal on Cybernetics and Informatics, Issue 2, Volume 5, 2016.

[10] M. Guruprasad, A. Arora, "Fuzzy Logic as a tool for evaluation of performance of Faculty in higher Education Systems", SHS web of Conference by EDP Sciences, 2016.

[11] G. Jyothi, P. Parvathi, "Fuzzy Expert model of Evaluation of faculty performance in Technical Education Institutions", International Journal of Engineering Research and Applications, Issue 4, Volume
5, pp. 41-50, 2014.

[12] A. Shout, M. K. Yousif, "Employee Performance Appraisal System using Fuzzy logic", International Journal of Computer Science and Information Technology (IJCSIT), Issue 6, Volume 4, pp. 1-19, 2014.

[13] M. H. Wang, C. S. Wang "Type 2 Fuzzy Set construction and Application for Adaptive Student Assessment System", IEEE internal conference on Fuzzy Systems (FUZZ-IEEE), pp. 888-894, 2014.

[14] R. S. Yadav, A. K. Soni, "A Study of Academic Performance Evaluation using Fuzzy Logic Techniques", In Proceedings of IEEE conference on Computing for Sustainable global development, pp. 48-53, 2014

[15] Z. Yildiz, A. F. Baba, "Evaluation of Student Performance in Laboratory Applications using Fuzzy Decision Support Model", In Proceedings of IEEE Global Engineering Education Conference (EDUCON), pp. 1023-1027, 2014

[16] N. Arora, J. K. Saini, "A Fuzzy Probabilistic Neural Network for student Academic Performance Evaluation ", International Journal of Innovative Research in Science, Issue 2, Volume 9, ISSN 2319-8573, 2013

[17] S. S. Jamsandekar, R. R. Mudholkar, "Performance Evaluation by Fuzzy Inference Technique", International Journal of Soft Computing and Engineering (IJSCE), Issue 3, Volume 2, pp. 158-164, ISSN 2231-2307, 2013. 